\title{
PERANAN PELATIH DALAM MEMOTIVASI PEMAIN SEPAKBOLA
}

\author{
Abd.Cholid \\ Dosen Prodi PKO - FKIP - Universitas PGRI Adi Buana Surabaya \\ abdcholid.coach@gmail.com
}

\begin{abstract}
Football is one of the most popular sport in Indonesia and the world. When the development isn't succeeded, the coaches' role would be reviewed as the responsibility is consideredto be found in them. When a match is succeded and meet their fans expectation, the coach would be praised. Otherwise, when a match isn't succeeded, the coach would be blamed. Therefore a coach needs to be able to motivate the players, because the players could be driven to win. To motivate, the coach needs to have a good mental state and good performance. With a good attitude and mental, the coach can be a good model for the players. Mental readiness and endurancce is very important to motivate the players. A coach needs to evaluate player's mental state so they keep improving.
\end{abstract}

Key word: coach, motivation

\section{A. Pendahuluan}

Prestasi sepakbola Indonesia yang kurang berhasil disebabkan oleh banyak faktor antara lain Sarana Prasarana, gizi dll, tapi yang lebih penting adalah Sumber Daya Manusia (SDM), karena dalam sepakbola kedudukan seorang pelatih memang cukup sulit kalaupun persiapan sudah matang kuwalitas permainan sudah sesuai dengan harapan tetapi tanpa gol tercipta kegawang lawan penilaian terhadap kemampuan seorang pelatih tetap kurang baik, oleh karena itu seorang pelatih harus bekerja keras sejak awal,

Pelatih harus memperhitungkan semua faktor positif dan faktor negatif yang akan timbul pada suatu saat, maka mutu program dan komunikasi pelatihan harus disesuaikan dengan keadaan para atlet atau para pemain, baik secara individu maupun tim, lingkungan, dan karakter para pemain itu sendiri.

Berhasil atau tidaknya suatu pelatihan dipengaruhi oleh beberapa faktor yang sifatnya sangat menentukan, dari sekian banyak faktor yang mempunyai dampak terhadap hasil pelatihan antara lain faktor Pelatih , pemain dan lingkungan, Sneyers J (1988). Begitu juga dalam proses pembelajaran Pelatih harus bisa menyampaikan pesan, motivasi secara jelas dan benar kepada para atlet. Untuk itu seorang
Pelatih harus mempunyai ilmu pendukung seperti psikologi olahraga, fisiologi, biomekanika, motor learning, ilmu gizi, ilmu kepelatihan dll, disamping pengalaman menjadi pemain, sehingga diharapkan dalam menyampaikan pesan, motivasi dengan jelas dan benar, serta mampu membaca situasi dan kondisi. Dengan demikian pesan yang disampaikan akan mudah ditangkap oleh para atlet, begitu juga dengan memotivasi yang jelas pelatihan akan terarah dan pasti akan terlihat hasilnya, keberhasilan tersebut salah satunya adalah motivasi dari pelatih, pengurus dan dari pemain itu sendiri. Sedangkan motivasi itu sendiri adalah proses yang menjelaskan intensitas, arah, dan ketekunan seorang individu untuk mencapai tujuan. (www.wikipedia.Org/wiki/motivasi).

\section{B. Pelatih Sepakbola}

Pelatih adalah Seseorang yang bertugas untuk mempersiapkan fisik dan mental olahragawan maupun kelompok olahragawan. (www.wikipedia.Org/Wiki/Pelatih), sedangkan menurut Ali Maksum dalam bukunya " Psikologi Olahraga teori dan aplikasinya" Pelatih dipahami sebagai orang yang dianggap ahli untuk mempersiapkan orang atau sejumlah orang untuk menguasai keterampilan tertentu, sedangkan pelatih sepakbola ada 
beberapa tingkatkan, menurut Cholid.A (2014) yaitu seperti tabel di bawah ini.

\section{Tabel Jenjang dan Kewenangan Kepelatihan di Sepakbola}

\begin{tabular}{|c|c|l|}
\hline No & Jenjang & \multicolumn{1}{|c|}{ Kewenangan } \\
\hline 1 & Lisensi D & $\begin{array}{l}\text { Pelatih yang hanya bisa } \\
\text { menjadi assisten pelatih } \\
\text { yang menangani tim yang } \\
\text { berkompetisi di tingkat } \\
\text { Divisi dua Nasional PSSI, } \\
\text { dan menjadi pelatih penuh } \\
\text { ditingkat SSB }\end{array}$ \\
\hline 2 & Lisensi C & $\begin{array}{l}\text { pelatih yang menangani tim } \\
\text { yang berkompetisi ditingkat } \\
\text { Divisi dua dan devisi satu } \\
\text { Nasional PSSI. }\end{array}$ \\
\hline 3 & Lisensi B & $\begin{array}{l}\text { Pelatih yang menangani tim } \\
\text { yang berkompetisi di tingkat } \\
\text { Divisi Utama Nasional } \\
\text { PSSI, dan menjadi asisten } \\
\text { pelatih Liga Super Nasional. }\end{array}$ \\
\hline 4 & Lisensi A & $\begin{array}{l}\text { Pelatih yang menangani tim } \\
\text { yang berkompetisi di tingkat } \\
\text { tertinggi nasional Indonesia } \\
\text { maupun ditingkat AFC } \\
\text { (Liga Super) }\end{array}$ \\
\hline
\end{tabular}

Sumber: Cholid.A (2014)

NASPE (Nasional Association For Sport and Physical Education) 2006, dalam situsnya, mengatakan kompetensi dan standar pelatih ada delapan (8) Domain :

Domain 1. Philosophy and Ethics,

Domain 2. Safety and Injury Prevention, Domain 3. Physical Conditioning.

Domain 4. Growth and Development,

Domain 5. Teaching and Communicatio, Domain 6. Sport Skill and Tactics,

Domain 7. Organization and Administration, Domain 8. Evaluation.

Sedangkan jenjang kepelatihan dan kewenangan menurut Lankor seperti terlihat pada tabel di bawah ini.
Tabel Jenjang dan Kewenangan Kepelatihan Lankor

\begin{tabular}{|c|c|c|}
\hline No & Jenjang & Kewenangan \\
\hline 1 & $\begin{array}{l}\text { Tingkat } \\
\text { pemula } \\
\text { (level 0) }\end{array}$ & $\begin{array}{l}\text { Instruktur olahraga } \\
\text { rekreasi/masyarakat } \\
\text { dalam system } \\
\text { pemasalan olahraga } \\
\text { dan pendidikan } \\
\text { jasmani yang } \\
\text { dilaksanakan pada } \\
\text { setiap lembaga } \\
\text { keolahragaan formal } \\
\text { maupun non formal } \\
\text { dan klub olahraga } \\
\text { yang memerlukannya. }\end{array}$ \\
\hline 2 & $\begin{array}{l}\text { Tingkat } \\
\text { Dasar } \\
\text { (level 1) }\end{array}$ & $\begin{array}{l}\text { Pelatih untuk atlet } \\
\text { tingkat pembibitan } \\
\text { pada tingkat klub } \\
\text { dan kabupaten/ kota. }\end{array}$ \\
\hline 3 & $\begin{array}{l}\text { Tingkat } \\
\text { Muda } \\
\text { (level II) }\end{array}$ & $\begin{array}{l}\text { Pelatih untuk tingkat } \\
\text { klub, kabupaten/ kota } \\
\text { dan provinsi. }\end{array}$ \\
\hline 4 & $\begin{array}{l}\text { Tingkat } \\
\text { Madya } \\
\text { (level } \\
\text { III) }\end{array}$ & $\begin{array}{l}\text { Pelatih untuk tingkat } \\
\text { klub, kabupaten/ kota } \\
\text { provinsi dan Nasional }\end{array}$ \\
\hline 5 & $\begin{array}{l}\text { Tingkat } \\
\text { utama } \\
\text { (level } \\
\text { IV) }\end{array}$ & $\begin{array}{l}\text { Pelatih pada tingkat } \\
\text { Internasional. }\end{array}$ \\
\hline
\end{tabular}

Sumber, Lankor 2008.

Prestasi Siswa/ Atlet negara maju ternyata tidak lepas dari konsep pembinaan yang bernuansa science (ilmu pengetahuan) dan art seni, karena pelatihan menuntut kreativitas dan interpretasi yang tinggi untuk memahami berbagai situasi dan kondisi yang berkembang.

Pate, Clenaghan, dan Rotella, (1984), mengemukakan bahwa Pelatih yang artistik dan kreatif harus didasarkan pada kemampuan ilmu yang menunjangnya.

\section{Sikap Mental dan Kinerja Pelatih.}

Keberhasilan suatu tim pada even sudah barangkali tidak terlepas dari faktor- 
faktor yang terkait dengan proses peningkatan prestasi, salah satu yang di maksud adalah sikap mental dan kinerja Pelatih, karena sikap mental dan kinerja Pelatih merupakan salah satu faktor yang paling menentukan dalam peningkatan prestasi dan keberhasilan suatu tim atau kesebelasan. Sikap mental dan kinerja Pelatih memegang peranan yang sangat penting dan merupakan elemen yang paling krusial dalam proses pelaksanaan pelatihan. Pelatih adalah ujung tombak di lapangan yang bersentuhan langsung dengan para atlet yang dilakukan secara teratur dan terprogram serta tersistematis.

Dalam Proses pelatihan, Pelatih berperan sebagai tokoh sentral yang akan menjadi panutan, pengayom serta sebagai subyek yang dapat membentuk pemain agar dapat memiliki daya cipta, rasa dan karsa sesuai dengan taksonomi pendidik yaitu meliputi usaha pengembangan pengetahuan (Cognetive Domain), Pembentukan watak dan sikap (Affective domain) serta melatih ketermpilan (Psychomotoric domain), oleh karena itu Pelatih selayaknya menyadari posisinya sebagai sosok yang mempunyai kapasitas dan kapabilitas untuk membentuk kemampuan mental dan kemampuan pemainnya agar mampu berbuat seperti yang dilakukan. Pelatih juga dapat dikatakan sebagai aktor utama sebuah tim atau kesebelasan yang berperan dalam proses pelatihan, sehingga mampu melahirkan pemain yang benar-benar berkuwalitas.

Berdasarkan uraian diatas, Pelatih sebagai pelaku utama dalam proses transfer of knowledge memiliki tanggung jawab besar dalam pembentukan kemampuan dan mental para pemainnya, oleh karenanya produktivitas kinerja pelatih perlu diperdayakan dan ditingkatkan. Sebagai tolak ukur dari kinerjanya dapat dilihat dari prestasi para Atletnya serta perilaku yang sesuai dengan norma-norma yang berlaku dalam masyarakat.

Pelatih adalah sosok manusia yang selalu memposisikan dirinya sebagai figur yang berambisi untuk selalu sukses dalam tugas. Oleh karena itu,
Menurut Harsuki (2003), pelatih harus tampil selalu dengan pola kerja keras, berdisiplin, berwibawa dan rendah hati namun tetap cermat dengan berbagai tantangan dan persaingan untuk mencapai prestasi tinggi.

Beberapa pola kepemimpinan pelatih:

\section{Pola kepemimpinan pelatih}

Pola kepemimpinan diartikan sebagai caracara seorang pelatih bersosialisasi pada para atlet.

\section{Pola kepemimpinan otoriter}

Pola kepemimpinan otoriter dapat terjadi apabila pelatih ingin menguasai seluruh kegiatan pelatihan.

Unsur-unsur dari pola kepelatihan otoriter, antara lain:

a. Segala sesuatu yang berkaitan dengan atlet ditentukan oleh pelatih.

b. Setiap atlet hanya melakukan satu jenis perbuatan saja.

c. Dalam memberikan pujian (reward) dan hukuman (punishment) bersifat personal.

d. Dalam memberikan bimbingan bersifat pasif.

e. Pelatih tidak turut secara aktif.

\section{Pola kepemimpinan permisif}

Dalam pola kepemimpinan permisif, pelatih kurang tegas. Atlet menentukan sendiri apa yang dikehendaki. Pelatih tidak mempunyai kewibawaan dihadapan atletnya. Untuk mencapai prestasi dalam olahraga adalah melalui rangkaian proses kerja pelatih dan atlet yang sistematis. Pelatih harus membuat model pelatihan yang berbobot, sesuai tuntutan dan kriteria ilmiah, dan cocok untuk kebutuhan individu atlet.

Secara umum peran dan tugas pelatih adalah sebagai berikut:

1. Cermat menentukan sasaran atau tujuan pelatihan.

2. Menetapkan tujuan pelatihan yang bersifat realistik.

3. Memilih metode, model pelatihan yang cocok untuk memenuhi kebutuhan setiap pemain.

4. Memotivasi atlet untuk berlatih keras. 
5. Mencermati pelatihan pemanasan dan pencegahan cedera.

6. Memanfaatkan aspek pembinaan psikologis.

7. Cermat dan terampil melakukan seni berkomunikasi.

\section{Kesiapan dan Ketahanan Mental.}

Dalam menghadapi pertandingan atlet harus memiliki kesiapan mental disamping kesiapan fisik dan teknik. Kesiapan mental dalam olahraga berarti juga kesiapan mental untuk menghadapi segala kemungkinan yang dapat terjadi dalam bertanding, jauh-jauh hari sebelum menghadapi pertandingan atlet perlu dibina kondisi mentalnya. Kesiapan mental adalah keadaan mental seseorang dimana sumber-sumber kemampuan jiwanya yaitu akal, kehendak dan emosi siap untuk melakukan tugas sesuai kemampuannya, karena kesiapan mental yang kurang baik akan mengakibatkan seseorang tidak dapat menanggung beban mental yang seharusnya ia dapat menanggungnya, dengan kata lain individu yang bersangkutan tidak dapat melakukan tugas dengan baik yang seharusnya individu tersebut dapat melakukannya.

Sesuai dengan prinsip psiko-fisik sebagai kesatuan yang bersifat organik, maka kondisi mental yang kurang baik akan mempengaruhi kesiapan fisik untuk melakukan tugasnya dengan baik, sehingga individu yang bersangkutan tidak dapat mencapai prestasi yang diharapkan. Disamping kesiapan mental menghadapi pertandingan Atlet juga perlu dilatih, sehingga Atlet memiliki ketahanan mental dan mampu mengatasi keadaan tertentu yang membutuhkan mental yang kuat untuk menghadapi cemohan dan gangguan dari penonton, dan juga menghadapi ancaman dari lawan bertanding dan gangguan lainnya. Baik mengenai kesiapan mental maupun ketahanan mental keduanya selalu ada kaitannya dengan sumber kemampuan jiwa manusia yaitu kemauan, perasaan, dan akal manusia yang dapat mempengaruhi rasa dan kehendak manusia, rasa manusia dapat mempengaruhi akal, rasa manusia dapat mempengaruhi kehendak untuk mendapat kepuasan, sumber kemampuan manusia merupakan satu kesatuan yang tidak dapat dipisahkan, dan saling mempengaruhi satu dengan yang lainnya. Disamping saling mempengaruhi antara sumber kemampuan jiwa manusia, ada juga yang saling mempengaruhi antara kemampuan jiwa dengan proses-proses jasmaniah, yaitu individu yang sedang marah denyut jantung bertambah cepat dan sebagainya.

\section{E. Mengevaluasi Meningkat dan Merosotnya Atlet}

Strategi mental training dan perlakuan (treatment) yang dilatihkan harus disesuaikan dengan keadaan individual atlet, selain harus disesuaikan dengan keadaan sebagian besar anggota tim, karena ada mental training untuk tim dan ada juga mental training yang ditujukan pada atlet orang perorang. Sehubungan itu perlu diketahui beberapa gejala, yang sering terjadi pada Atlet, baik gejala yang perlu dikembangkan, maupun gejala-gejala yang dapat menimbulkan gangguan atau hambatan pencapaian prestasi. Mental training yang dilatihkan harus disesuaikan dengan kelemahan dan potensi yang perlu dikembangkan terhadap Atlet yang menunjukkan gejala "over confidence" tentu lain perlakuannya yang diberikan kepada Atlet yang menunjukkan gejala "lack of confidence" atau "Full confidence"

Penetapan strategi mental training
selain disesuaikan dengan sifat-sifat pembawaan, juga disesuaikan dengan situasi pada waktu itu, sedang menghadapi pertandingan yang menentukan, atau sesudah kalah pertandingan di mana seluruh anggota tim merasa terpukul dan merasa sangat malu terhadap kekalahan yang dialami. Pada dasarnya dapat dibedakan strategi jangka panjang dalam rangka membina kepribadian Atlet, dan strategi jangka pendek menghadapi pertandingan atau sesudah pertandingan. Di samping motivasi ada beberapa gejala psikologik yang sangat penting dan menentukan pencapaian prestasi, yaitu antara lain, percaya diri, rasa harga diri, disiplin dan tanggung jawab, penguasaan diri, sikap dan 
konsep diri. Di samping itu perlu selalu diperhatikan adanya gejala-gejala psikologik yang dapat menimbulkan gangguan, antara lain fatique dan staleness stress, anxiety, dan frustrasi. Agresivitas yang mengandung segisegi positif juga dapat berdampak negatif, dan perlu diperhatikan dalam upaya peningkatan prestasi.

Sebagai atlet pasti tidak selalu tampil optimal. Namun untuk meminimalisir merosotnya performa atlet, pelatih harus dapat memberikan motivasi bagi atlet yang sedang tidak dalam peak performance. Setiap pelatih harus memiliki program yang sistematis untuk mencapai tujuan tertentu. Keberhasilan dalam olahraga tidak datang dari pelatihan yang bermutu saja ketika atlet sedang merasa senang. Atlet harus memiliki arahan yang jelas agar ia dapat disiplin. Oleh karena itu, dibutuhkan pelatih yang penuh pengertian dan perhatian pada atletnya.

\section{F. Menetapkan Strategi Pembinaan Mental}

Semua upaya pembinaan mental, baik itu perlakuan sehari-hari, bimbingan dan konseling maupun mental training, harus terkait dengan tujuan akhir dari mental training maupun, pembinaan mental.

Ali Maksum (2008), Prinsip dasar pelatihan mental.

1. Manusia terdiri dari jiwa dan raga yang saling berinteraksi dan mempengaruhi satu sama lain.

2. Setiap manusia pasti menghadapi masalah,dan setiap masalah pasti ada cara penyelesaiannya.

3. Manusia pada hakekatnya adalah mahluk berkesadaran, karena itu tingkah laku yang ditampilkan dipengaruhi oleh kesadaran.

4. Manusia pada hakekatnya adalah mahluk yang bertujuan,karena itu tingkah laku manusia sebagian besar didorong oleh tujuan yang diinginkan.

5. Manusia pada hakekatnya bersifat aktif tidak hanya dipengaruhi oleh lingkungan melainkan juga mempengaruhi lingkungan

6. Manusia dalam perkembangannya dipengaruhi oleh faktor keturunan dan lingkungan.
7. Sebagaimana pelatihan fisik, pelatihan mental perlu dilakukan secara teratur, sistematis dan berkelanjutan.

Salah satu tujuan mental training adalah melatih bagaimana menemukan caracara untuk dapat mengontrol diri, cara yang biasa dilakukan sehari-hari untuk mengontrol sesuatu dengan kemampuan penuh kesadaran dan keteguhan hati. Kenyataan menunjukkan ada banyak faktor psikologik yang berkaitan dengan tingkah laku manusia dalam kehidupan sehari-hari dan juga dalam olahraga. Untuk dapat menerapkan program mental training pada seorang atlet perlu terlebih dahulu diteliti keadaan atau kondisi dan perkembangan mental, serta sifat-sifat dan kemampuan mental atlet yaitu mendiagnosa keadaan dan perkembangan mental atlet, menetapkan sasaran-sasaran dengan mengacu pada tujuan dan target yang akan dicapai, selanjutnya menetapkan strategi, dan langkah-langkah utama untuk menetapkan mental training yang akan diterapkan. Pada hakekatnya mental training dimaksudkan untuk (1) Meningkatkan keterampilan mental (mental skills); (2) Meningkatkan kekuatan mental (mental power).tapi kenyataan menunjukkan adanya perbedaan individual atlet satu dengan atlet yang lain, maka mental training harus dilakukan atas dasar pendekatan individual. Pendekatan individual dapat dilakukan atas dasar perbedaan sifat-sifat kepribadian, perbedaan motivasi, serta pemikiran dan perasaan yang berbeda.

Ali Maksum, 2008, Kepribadian adalah seperangkat ciri atau karakteristik, yang relatif menetap dan terorganisasikan dalam diri individu, yang mempengaruhi tingkah laku individu tsb. Motivasi yang berbeda antara individu juga membutuhkan perlakuan yang berbeda. Atlet yang memiliki motivasi prestasi tinggi membutuhkan perlakuan yang berbeda dengan atlet yang tidak bermotivasi prestasi tinggi. Atlet yang memiliki motivasi prestasi tinggi cukup dengan diberikan stimulasi sudah akan berusaha sendiri mencapai tujuannya, sedangkan atlet yang kurang memiliki motivasi prestasi tinggi mungkin memerlukan dorongan, bahkan 
mungkin tantangan-tantangan dan ancaman agar atlet yang bersangkutan berusaha sekeraskerasnya mengejar prestasi. Penetapan "target antara" untuk mencapai tujuan yang ditetapkan (goal setting) merupakan salah satu metode yang banyak digunakan dalam menumbuhkan dan memelihara motivasi berprestasi, karena prestasi sangat erat hubungannya dengan kuat atau lemahnya motivasi berprestasi, namun tidak boleh diabaikan juga adanya motivsi lain yang besar pengaruhnya terhadap kegairahan atlet mencapai prestasi setinggi-tingginya, yaitu motivasi untuk mendapatkan keuntungan materi, motivasi harga diri, motivasi ketergantungan dan sebagainya

Salah satu upaya penting dalam mental training adalah menumbuhkan pemikiran positif (positive thinking) terhadap sekitar terhadap diri sendiri dan gambaran tentang pribadi ideal, yang diharapkan akan membentuk citra diri. Citra diri dan persepsi diri yang berbeda-beda akan menghasilkan sikap dan tindakan yang berbeda, oleh karena itu untuk mencapai prestasi yang tinggi dan agar sesuai dengan harapan, maka peran pelatih sangat dibutuhkan dalam memotivasi para atletnya untuk mencpai tujuan tersebut.

\section{Simpulan}

Sepakbola adalah olahraga yang paling terkenal di Indonesia bahkan di dunia. Apabila dalam pembinaan kurang berhasil, maka yang paling pertama disorot adalah peranan pelatih, karena pelatih dianggap yang bertanggung jawab dalam setiap pertandingan. Bila pertandingan itu berhasil dan sesuai harapan pecintanya, maka pelatih tersebut akan disanjung-sanjung, tapi apabila dalam suatu pertandingan tidak berhasil (kalah), maka pelatih akan dihujat. Oleh karena itu seorang pelatih harus pandai dalam memotivasi pemainnya, karena dengan motivasi yang baik pemain akan terdorong untuk memenangkan pertandingan.

\section{Daftar Pustaka}

Cholid. A. (2014), Evaluasi Pelaksnaan SSB di Pengprov PSSI Jawa Timur, Disertasi Doktor Unesa Surabaya.
Harsuki. (2003) Perkembangan Olahraga Terkini. Jakarta: PT. RajaGrafindo Persada.

Lankor Jenjang dan kewenangan kepelatihan (2008) $h t t p / / w w w$, lankor/indek; phpoption $=\mathrm{com}$ content\&task $=$ view $\& i d=38 \&$ Itemid $=51,03$ Januari 2008, Diakses, 25 Agustus 2013

Maksum, Ali. (2008) Psikologi Olahraga: Teori dan Aplikasinya. Surabaya: Unesa University Press.

Naspe. 2006. Coaching Football For Dummies. Indiana: Wiley Publishing, Inc. Diakses 12 Mei 2013.

Pate, Clenaghan. Rotella 1984. Scientific Fundation of Coaching. Amerika. CBS College Publishing. Diakses 12 Mei 2013

Sneyers. 1988. Sepakbola: Latihan dan Stralegi Bermain. Jakarta: Rosda Jaya Putra.

http:www.id.wikipedia.Org/Wiki/Pelatih. diakses pada 21 Juli 2013.

http:www.id.wikipedia.Org/wiki/motivasi. diakses, 22 Juli 2013. 